\title{
Potensi Dimer A3-APO untuk Mengontrol Populasi Escherichia coli Resisten Obat: Sebuah Tinjauan Pustaka
}

The Role of Dimer A3-APO as Drug Resistant-Escherichia coli Population Controller: a Literature Review

\author{
Ignatius Ivan", Harvey Sudharta, Kevin Tandarto, Fanny Budiman, Maureen M \\ Stella \\ Fakultas Kedokteran dan Ilmu Kesehatan, Universitas Katolik Indonesia Atma Jaya \\ Jl. Pluit Raya No. 2, Pluit, Penjaringan, Jakarta Utara \\ *Penulis korespondensi \\ Email: ignatiusivan98@gmail.com
}

Received: September 30, 2020

Accepted: July 30, 2021

\begin{abstract}
Abstrak
Peningkatan penggunaan antibiotik yang tidak terkontrol saat ini dapat memicu terjadinya resistensi bakteri. Penggunaan antibiotik di dunia meningkat hingga 36\% dalam kurun waktu 10 tahun. Pada sektor peternakan penggunaan antibiotik saat ini mencapai level yang mengkhawatirkan, dimana $80 \%$ pada peternakan unggas, $75 \%$ pada peternakan babi, $60 \%$ pada peternakan sapi potong, dan $75 \%$ pada peternakan sapi perah. Kajian ini membahas berbagai metode yang dapat digunakan untuk mengontrol populasi bakteri Escherichia coli resisten antibiotik. Tujuan dilakukan kajian ini adalah untuk mencari metode yang paling baik dalam upaya mengontrol populasi bakteri Escherichia coli. Metode penelitian adalah tinjauan pustaka terhadap literatur yang bersumber dari Google Scholar dan ProQuest. Sebanyak 352 artikel ditemukan dengan search engine Google Scholar dan ProQuest pada tahap skrining abstrak. Setelah artikel full-text dilakukan skrining berdasarkan inklusi dan eksklusi maka didapat 10 artikel yang relevan untuk dibahas pada studi ini. Sebagai simpulan, metode yang paling baik dilakukan dalam upaya mengontrol populasi bakteri Escherichia coli resisten adalah dengan mengganggu dan merusak aktivitas protein folding bakteri dengan dimer A3-APO yang merupakan suatu peptida antimikroba dengan hasil efektivitas sebesar 99\%-100\%.
\end{abstract}

Kata kunci: dimer A3-APO; obat; bakteri; mikrobiologi, antibiotik

\begin{abstract}
Increasing uncontrolled use of antibiotics at this time can lead to bacterial resistance. The use of antibiotics in the world increased by $36 \%$ in 10 years. In the livestock sector, the use of antibiotics is currently reaching an alarming level, where $80 \%$ in poultry farming, $75 \%$ in pig farms, $60 \%$ in beef cattle, and $75 \%$ in dairy farming. This study discusses various methods that can be used to control the population of antibiotic-resistant Escherichia coli bacteria. The purpose of this study was to find the best method in controlling the population of Escherichia coli bacteria. The research method is a literature review of the literature sourced from Google Scholar and ProQuest. A total of 352 articles were found on the Google Scholar and ProQuest search engines at the abstract screening stage. After full-text article were screened by inclusion and exclusion criteria, 10 articles were obtained that were relevant to be discussed in this study. In conclusion, the best method to control the population of resistant Escherichia coli bacteria is to
\end{abstract}




\section{Review Article}

disrupt and destroy the protein folding activity of bacteria with A3-APO dimer which is an antimicrobial peptide with an effectiveness of 99\% $-100 \%$.

Keywords: dimer A3-APO, drug; bacteria; microbiology; antibiotics

\section{Pendahuluan}

Dalam kurun waktu 2 dekade terakhir, penggunaan antibiotik baik pada manusia maupun hewan mengalami peningkatan secara signifikan yang disebabkan oleh kemudahan masyarakat dalam memperoleh antibiotik. Menurut studi yang dilakukan oleh Boeckel et al. telah terjadi peningkatan dalam penggunaan antibiotik hingga 36\% dalam kurun waktu 10 tahun. ${ }^{1}$

Penggunaan antibiotik dalam peternakan saat ini mencapai level yang mengkhawatirkan yaitu mencapai $80 \%$ pada peternakan unggas, $75 \%$ pada peternakan babi, $60 \%$ pada peternakan sapi potong, dan $75 \%$ pada peternakan sapi perah. Peningkatan penggunaan antibiotik di bidang peternakan ini disebabkan oleh pemberian antibiotik pada hewan dapat memberikan manfaat berupa pertumbuhan badan hewan yang semakin besar dan sehat. Pemberian antibiotik juga dapat mengobati hewan ternak dari penyakit infeksi. Hal ini dapat dilihat misalnya pada penyakit kolibasiolosis yang disebabkan oleh bakteri Escherichia coli (E. coli) pada babi ternak yang prevalensinya masih tinggi. Hal ini disebabkan oleh babi yang ketika terinfeksi kolibasiolosis akan mengalami diare dan dapat mengalami kematian. Kematian ternak ini tentu menyebabkan kerugian ekonomi sehingga memaksa petani untuk menggunakan antibiotik. Menurut studi yang dilakukan oleh Boeckel et al. pada tahun 2010 hingga tahun 2030 akan terjadi peningkatan dalam penggunaan antibiotik di bidang peternakan hingga $67 \%$ dengan $99 \%$ dari peningkatan terjadi pada 5 negara dengan ekonomi terbesar yaitu Brasil, Russia, India, China, dan Afrika Selatan (BRICS). ${ }^{2,3}$

Penyalahgunaan antibiotik pada manusia juga mengalami peningkatan dari tahun ke tahun. Tingkat resistensi bakteri di Indonesia meningkat dari tahun 2013 (40\%), 2016 (60\%), hingga $2019(60,4 \%) .{ }^{3}$ Fenomena penyalahgunaan antibiotik ini sebagian besar dilakukan oleh masyarakat umum secara luas. Masyarakat cenderung untuk membeli, menyimpan, dan menggunakan antibiotik tanpa resep dokter. ${ }^{4}$ Di bidang peternakan, antibiotik digunakan untuk penggemukan hewan peternakan. Dampak penggunaan antibiotik pada hewan peternakan secara luas adalah manusia yang memakan daging hewan ternak tersebut cenderung menjadi resisten terhadap antibiotik. Dampak buruk lain karena resistensi tersebut adalah tenaga kesehatan khususnya dokter akan kesulitan memberikan terapi antibiotik. ${ }^{5}$ 


\section{Review Article}

Menurut studi, sebanyak $80 \%$ penggunaan antibiotik terjadi pada luar rumah sakit. Pada penjualan 3.000 antibiotik di Hanoi, Vietnam, ditemukan bahwa 88-91\% penjualan yang terjadi dilakukan tanpa adanya resep dokter. Hal ini menunjukkan betapa mudahnya masyarakat dalam memperoleh antibiotik. ${ }^{3,4}$ Data statistik penyalahgunaan antibiotik di Indonesia mencapai $60,4 \%$ pada tahun 2019, lebih tinggi jika dibandingkan dengan tahun-tahun sebelumnya yaitu hanya sebesar 40\% pada tahun 2017 dan 60\% pada tahun 2018.5,6

Menurut data WHO tahun 2015, beberapa bakteri resisten terhadap antibiotik lini terakhir. Data menunjukkan bahwa E. coli yang resisten terhadap sefalosporin generasi ke-tiga sebesar 95\%, dan E. coli resisten terhadap siprofloksasin 96\%, kemudian Streptococcus pneumoniae resisten terhadap golongan makrolid 76\%, Staphylococcus aureus resisten metisilin 82\%, Pseudomonas aeruginosa resisten terhadap karbapenem 38\% dan Acinetobacter baumanii resisten terhadap karbapenem $62 \%{ }^{7,8}$ Data penelitian lain menunjukkan bahwa bakteri E.coli mengalami resistensi sebesar $97,3 \%$ terhadap antibiotik tetrasiklin, 87,8\% terhadap sulfamethoxazole, 74,3\% terhadap trimethoprim, 68,9\% terhadap ampisilin, 64,8\% terhadap nalidixic acid, 45,9\% terhadap ciprofloxacin, 40,5\% terhadap enrofloxacin, 28,4\% terhadap gentamisin, dan 10,8\% terhadap kloramfenikol. ${ }^{9}$ Studi yang dilakukan oleh Kumari et al., pada tahun 2017 menyatakan bahwa peningkatan bakteri resisten paling mengkhawatirkan adalah bakteri resisten karbapenem dan polimiksin karena kedua antibiotik ini dianggap sebagai pengobatan lini terakhir yang sampai saat ini belum ditemukan alternatif pengobatan pengganti. ${ }^{9}$ Tanpa adanya usaha dalam mengontrol populasi bakteri resisten ini, dikhawatirkan angka kematian khususnya di negara berkembang meningkat pesat. ${ }^{10}$

Kemunculan antibiotik baru selalu diikuti kemunculan bakteri resisten dalam jangka kurun waktu 3 tahun. ${ }^{11}$ Penyebaran gen resisten sebagian besar terjadi melalui mekanisme pemindahan plasmid dari satu bakteri ke bakteri lainnya melalui konjugasi. Keberadaan bakteri resisten ini sangat mengkhawatirkan karena menyebabkan obat yang selama ini dapat digunakan menjadi tidak efektif atau harus ditingkatkan dosisnya yang dampaknya dapat memberi efek toksik berbahaya bagi tubuh manusia. ${ }^{11,12}$ Dampak buruk resistensi antibiotik terhadap manusia adalah ketika seseorang mengalami infeksi yang disebabkan oleh bakteri maka pemberian antibiotik untuk menyembuhkannya sulit berhasil, sehingga dapat meningkatkan angka morbiditas dan mortalitas di kemudian hari. Hal ini juga menyebabkan rencana pemberian terapi yang sesuai oleh dokter kepada pasien akan terganggu. ${ }^{13}$

Eschericia coli adalah spesies bakteri yang merupakan komponen umum flora normal di dalam usus manusia. Setiap mahluk hidup berdarah panas memiliki bakteri ini di dalam ususnya. 


\section{Review Article}

Bakteri E. coli selalu terekspos terhadap makanan yang kita konsumsi sehari-hari, yang mungkin mengandung bakteri resisten. Bakteri $E$. coli disebut juga sebagai reservoir karena sering terjadi kontak dengan bakteri lain dan mudah memperoleh gen resisten. Bakteri E. coli merupakan salah satu penyebab penyakit yang paling umum di dunia, oleh karena itu bakteri ini harus dicegah sehingga tidak menjadi resisten terhadap antibiotik. ${ }^{10}$

Dalam kajian ini metode-metode untuk mengontrol populasi E. coli yang resisten terhadap antibiotik serta mengkaji metode yang paling efektif bagi pengobatan bakteri E. coli yang resisten antibiotik akan dipaparkan dan dianalisis. Beberapa metode yang digunakan untuk mengontrol populasi bakteri E.coli resisten obat adalah dengan Dimer A3-APO, plasmid, CRISP$\operatorname{Cas} 9$, nanopartikel, dan inhibisi konjugasi. Beberapa metode tersebut terbuktif efektif untuk mengontrol populasi bakteri E.coli yang resisten obat. Tujuan dilakukan kajian ini adalah untuk mencari metode yang paling baik dalam upaya mengontrol populasi bakteri Escherichia coli.

\section{Metode}

Metode penelitian adalah tinjauan pustaka terhadap literatur yang bersumber dari Google Scholar dan ProQuest. Literatur yang dipilih adalah literatur yang menggunakan metode eksperimental, tinjauan pustaka, dan kajian sistematis. Pencarian jurnal dilakukan menggunakan kata kunci Dimer A3-APO, plasmid, CRISP-Cas9, nanoparticle, conjugation inhibition, drug resistant, drug resistants, Escherichia coli, drug resistance, drugs resistant, antibiotic resistance, antibiotic resistant, antibiotics resistance, antibiotics resistance, antimicrobial drugs resistance, antimicrobial resistant, antimicrobial drug resistance, antimicrobial drug resistant. Setelah penelusuran dilakukan pemeriksaan duplikasi artikel menggunakan Zotero, sistem journal manager yang berbasis open source.

Kriteria inklusi penelitian adalah jurnal yang membahas tentang bakteri E.coli yang resisten terhadap pengobatan, metode untuk pengobatan alternatif bakteri E.coli yang resisten antibiotik, terbit antara tahun 2010-2020, berbahasa Inggris, dan dipublikasi pada peer-reviewed journal. Kriteria eksklusi penelitian adalah artikel yang tidak menyediakan full-text, tidak berbahasa Inggris dan Indonesia, serta tidak membahas jenis metode untuk melawan bakteri E.coli yang resisten antibiotik. Seluruh hasil literasi jurnal dinilai risiko bias dengan menggunakan Newcastle Ottawa Scale.

Seluruh hasil literasi yang memenuhi kriteria inklusi dikaji oleh minimal 2 reviewer yang sudah berpengalaman pada bidang penelitian secara independent. Data ditelaah secara mandiri 


\section{Review Article}

oleh 2 reviewer dalam tahap penentuan ini. Reviewer tersebut memilih literasi sesuai kriteria inklusi untuk diikutsertakan ke dalam studi ini. Apabila terdapat perbedaan pendapat antara 2 reviewer tersebut maka akan dikonsultasikan kepada reviewer ke-tiga. Setelah dilakukan skrining abstrak dan penyaringan artikel jurnal untuk diinklusi, selanjutnya dilakukan eksklusi penelitian yang tidak relevan.

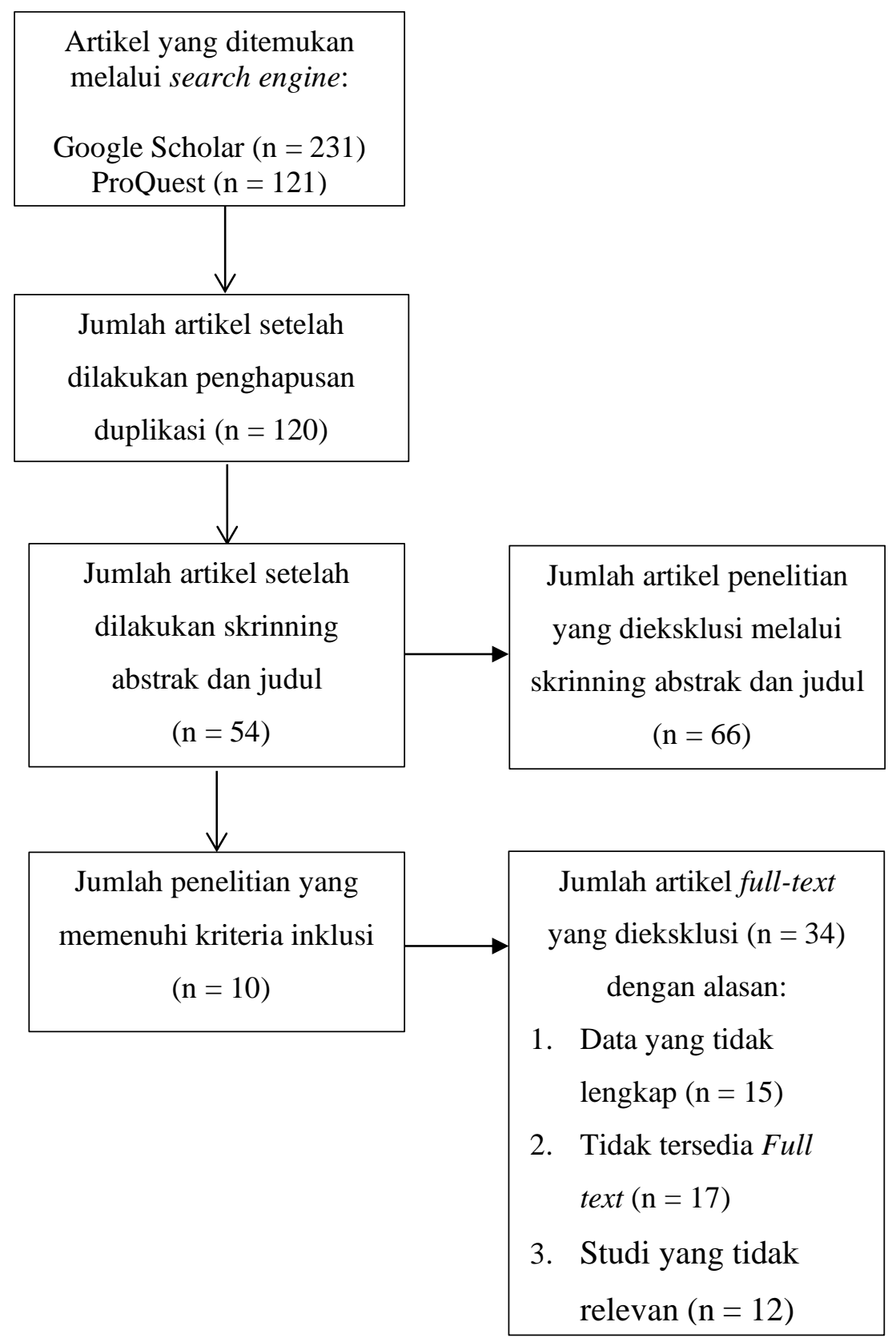

Gambar 1. Alur Literature Searching Berdasarkan Kriteria Inklusi dan Eksklusi 


\section{Review Article}

\section{Hasil}

Sebanyak 231 artikel ditemukan dengan search engine Google Scholar, dan 121 artikel ditemukan dengan search engine ProQuest pada tahap awal skrining abstrak. Setelah dilakukan inklusi dan eksklusi maka didapat 10 artikel yang relevan untuk dibahas pada studi ini. Seluruh artikel jurnal yang memenuhi syarat pada penelitian ini dicantumkan pada sumber referensi jurnal ini.

Tabel 1. Tabel Abstraksi Artikel

\begin{tabular}{|c|c|c|c|c|c|}
\hline $\begin{array}{c}\text { Nama } \\
\text { Peneliti }\end{array}$ & Tahun & $\begin{array}{c}\text { Jenis } \\
\text { Penelitian } \\
\text { yang } \\
\text { dilakukan }\end{array}$ & Judul Penelitian & Metode Penelitian & $\begin{array}{l}\text { Hasil dari } \\
\text { Penelitian }\end{array}$ \\
\hline $\begin{array}{l}\text { Gomaa } \\
\text { et al. }\end{array}$ & 2014 & $\begin{array}{l}\text { Penelitian } \\
\text { Eksperimental }\end{array}$ & $\begin{array}{l}\text { Programmable } \\
\text { Removal of } \\
\text { Bacterial Strains } \\
\text { by Use of } \\
\text { GenomeTargetin } \\
\text { g CRISPR-Cas } \\
\text { Systems }\end{array}$ & $\begin{array}{l}\text { Menggunakan } \\
\text { bakteri E.coli strain } \\
\text { K-12 BW25113 } \\
\text { dengan tranduksi } \\
\text { P1. Selanjutnya } \\
\text { menggunakan } \\
\text { CRISPR-Cas9 untuk } \\
\text { melihat } \\
\text { pertumbuhan dari } \\
\text { bakteri E.coli }\end{array}$ & $\begin{array}{l}\text { Sistem CRISP- } \\
\text { Cas9 berpotensi } \\
\text { menghapus strain } \\
\text { dari bakteri yang } \\
\text { menjadi } \\
\text { penyabab resisten } \\
\text { terhadap } \\
\text { antibiotik }\end{array}$ \\
\hline $\begin{array}{l}\text { Cui \& } \\
\text { Bikard }\end{array}$ & 2016 & $\begin{array}{l}\text { Penelitian } \\
\text { Eksperimental }\end{array}$ & $\begin{array}{l}\text { Consequences of } \\
\text { Cas } 9 \text { cleavage in } \\
\text { the chromosome } \\
\text { of Escherichia } \\
\text { coli }\end{array}$ & $\begin{array}{l}\text { Bakteri strain E.coli } \\
\text { ditumbuhkan pada } \\
\text { Luria-Bertani agar. } \\
\text { pCRRNA atau } \\
\text { plasmid pCas9 } \\
\text { dilakukan } \\
\text { transformasi pada } \\
\text { bakteri E.coli }\end{array}$ & $\begin{array}{l}\text { Cas9 berpotensi } \\
\text { untuk membunuh } \\
\text { bakteri E.coli } \\
\text { resisten antibiotik } \\
\text { dengan } \\
\text { memotong } \\
\text { kromosom dan } \\
\text { dilakukan } \\
\text { modifikasi gen }\end{array}$ \\
\hline $\begin{array}{l}\text { Kumari } \\
\text { et al. }\end{array}$ & 2017 & $\begin{array}{l}\text { Penelitian } \\
\text { Eksperimental }\end{array}$ & $\begin{array}{l}\text { Tailoring shape } \\
\text { and size of } \\
\text { biogenic silver } \\
\text { nanoparticles to } \\
\text { enhance } \\
\text { antimicrobial } \\
\text { efficacy against } \\
\text { MDR bacteria. }\end{array}$ & $\begin{array}{l}\text { Menggunakan } \\
\text { nanopartikel silver } \\
\text { (50-100 nm) yang } \\
\text { berbentuk sferis, } \\
\text { persegi panjang, dan } \\
\text { hexagonal. Diteliti } \\
\text { efeknya terhadap } \\
\text { bakteri Shigella } \\
\text { sonnei, Escherichia } \\
\text { coli, Serratia } \\
\text { marcescens, } \\
\text { Staphylococcus } \\
\text { aureus, dan } \\
\text { Pseudomonas } \\
\text { aeruginosa }\end{array}$ & $\begin{array}{l}\text { Efek } \\
\text { antimikrobial } \\
\text { paling baik } \\
\text { menggunakan } \\
\text { nanopartikel } \\
\text { berbentuk sferis } \\
(2-5 \mathrm{~nm}) \text { dengan } \\
\text { kombinasi } \\
\text { ampisilin dan } \\
\text { penisilin }\end{array}$ \\
\hline
\end{tabular}




\section{Review Article}

\begin{tabular}{|c|c|c|c|c|c|}
\hline $\begin{array}{c}\text { Nama } \\
\text { Peneliti }\end{array}$ & Tahun & $\begin{array}{c}\text { Jenis } \\
\text { Penelitian } \\
\text { yang } \\
\text { dilakukan }\end{array}$ & Judul Penelitian & Metode Penelitian & $\begin{array}{l}\text { Hasil dari } \\
\text { Penelitian }\end{array}$ \\
\hline $\begin{array}{l}\text { Rai et } \\
\text { al. }\end{array}$ & 2012 & $\begin{array}{l}\text { Penelitian } \\
\text { Tinjauan } \\
\text { Pustaka }\end{array}$ & $\begin{array}{l}\text { Silver } \\
\text { nanoparticles: } \\
\text { the powerful } \\
\text { nanoweapon } \\
\text { against } \\
\text { multidrug- } \\
\text { resistant } \\
\text { bacteria }\end{array}$ & $\begin{array}{l}\text { Telaah jurnal } \\
\text { tentang efek } \\
\text { nanopartikel perak } \\
\text { terhadap efek } \\
\text { antimikroba }\end{array}$ & $\begin{array}{l}\text { Nanopartikel } \\
\text { perak dapat } \\
\text { membunuh } \\
\text { bakteri E.coli } \\
\text { dengan cara } \\
\text { menembus } \\
\text { membran sel dan } \\
\text { mempengaruhi } \\
\text { replikasi DNA }\end{array}$ \\
\hline $\begin{array}{l}\text { Lin et } \\
\text { al. }\end{array}$ & 2011 & $\begin{array}{l}\text { Penelitian } \\
\text { Eksperimental }\end{array}$ & $\begin{array}{l}\text { Inhibition of } \\
\text { Bacterial } \\
\text { Conjugation by } \\
\text { Phage M13 and } \\
\text { Its Protein g3p: } \\
\text { Quantitative } \\
\text { Analysis and } \\
\text { Model }\end{array}$ & $\begin{array}{l}\text { Telaah jurnal } \\
\text { tentang efek inhibisi } \\
\text { konjugasi bakteri } \\
\text { dengan phage M13 } \\
\text { dan protein g3p }\end{array}$ & $\begin{array}{l}\text { Konjugasi } \\
\text { plasmid } \\
\text { berpotensi untuk } \\
\text { membunuh } \\
\text { bakteri E.coli } \\
\text { yang poliresisten } \\
\text { terhadap terapi } \\
\text { antimikroba }\end{array}$ \\
\hline $\begin{array}{l}\text { Szabo } \\
\text { et al. }\end{array}$ & 2010 & $\begin{array}{l}\text { Penelitian } \\
\text { Eksperimental }\end{array}$ & $\begin{array}{l}\text { The designer } \\
\text { proline-rich } \\
\text { antibacterial } \\
\text { peptide A3-APO } \\
\text { is effective } \\
\text { against systemic } \\
\text { Escherichia coli } \\
\text { infections in } \\
\text { different mouse } \\
\text { models }\end{array}$ & $\begin{array}{l}\text { A3-APO untuk } \\
\text { melihat potensi } \\
\text { melawan bakteri } \\
\text { E.coli yg resisten } \\
\text { terhadap antibiotik }\end{array}$ & $\begin{array}{l}\text { Peptida A3-APO } \\
\text { memiliki potensi } \\
\text { dalam melawan } \\
\text { bakteri E.coli dan } \\
\text { bakteri lainnya } \\
\text { yang poliresisten } \\
\text { terhadap } \\
\text { antibiotik }\end{array}$ \\
\hline $\begin{array}{l}\text { Zhang } \\
\text { et al. }\end{array}$ & 2014 & $\begin{array}{l}\text { Penelitian } \\
\text { Eksperimental }\end{array}$ & $\begin{array}{l}\text { In vitro } \\
\text { synergistic } \\
\text { activities of } \\
\text { antimicrobial } \\
\text { peptide brevinin- } \\
2 \text { CE with five } \\
\text { kinds of } \\
\text { antibiotics } \\
\text { against } \\
\text { multidrug- } \\
\text { resistant clinical } \\
\text { isolates }\end{array}$ & $\begin{array}{l}\text { Menggunakan } \\
\text { brevinin-2CE serta } \\
\text { kombinasi dari } 5 \\
\text { antibiotik untuk } \\
\text { melawan bakteri } \\
\text { E.coli penghasil } \\
\text { beta-lactamase dan } \\
\text { Staphylococcus } \\
\text { aureus resisten } \\
\text { methicillin }\end{array}$ & $\begin{array}{l}\text { Brevinin-2CE } \\
\text { berpotensi } \\
\text { membunuh } \\
\text { bakteri E.coli } \\
\text { dengan } \\
\text { mekanisme } \\
\text { melewati pore } \\
\text { dari bakteri } \\
\text { tersebut dan } \\
\text { menyebabkan } \\
\text { permeabilitas } \\
\text { membran } \\
\text { meningkat } \\
\text { terhadap bakteri }\end{array}$ \\
\hline
\end{tabular}




\section{Review Article}

\begin{tabular}{|c|c|c|c|c|c|}
\hline $\begin{array}{l}\text { Nama } \\
\text { Peneliti }\end{array}$ & Tahun & $\begin{array}{c}\text { Jenis } \\
\text { Penelitian } \\
\text { yang } \\
\text { dilakukan }\end{array}$ & Judul Penelitian & Metode Penelitian & $\begin{array}{l}\text { Hasil dari } \\
\text { Penelitian }\end{array}$ \\
\hline $\begin{array}{l}\text { Krizsan } \\
\text { et al. }\end{array}$ & 2015 & $\begin{array}{l}\text { Penelitian } \\
\text { Eksperimental }\end{array}$ & $\begin{array}{l}\text { Influence of the } \\
\text { yjiL-mdtM Gene } \\
\text { Cluster on the } \\
\text { Antibacterial } \\
\text { Activity of } \\
\text { Proline-Rich } \\
\text { Antimicrobial } \\
\text { Peptides } \\
\text { Overcoming } \\
\text { Escherichia coli } \\
\text { Resistance } \\
\text { Induced by the } \\
\text { Missing SbmA } \\
\text { Transporter } \\
\text { System }\end{array}$ & $\begin{array}{l}\text { Menggunakan } \\
\text { peptida yang } \\
\text { disintesis dari amide } \\
\text { 4- } \\
\text { methylbenzhydryla } \\
\text { mine (MBHA) } \\
\text { untuk melihat } \\
\text { potensi antimikroba } \\
\text { terhadap bakteri } \\
\text { E.coli }\end{array}$ & $\begin{array}{l}\text { PrAMP yang } \\
\text { dihasilkan dari } \\
\text { peptida } \\
\text { berpotensi } \\
\text { memiliki efek } \\
\text { antimikroba } \\
\text { terhadap bakteri } \\
\text { E.coli yang } \\
\text { resisten obat dan } \\
\text { bakteri lainnya } \\
\text { melalui } \\
\text { mekanisme } \\
\text { transporter }\end{array}$ \\
\hline $\begin{array}{l}\text { Knappe } \\
\text { et al. }\end{array}$ & 2016 & $\begin{array}{l}\text { Penelitian } \\
\text { Eksperimental }\end{array}$ & $\begin{array}{l}\text { Proline-rich } \\
\text { Antimicrobial } \\
\text { Peptides } \\
\text { Optimized for } \\
\text { Binding to } \\
\text { Escherichia coli } \\
\text { Chaperone } \\
\text { DnaK }\end{array}$ & $\begin{array}{l}\text { Menggunakan target } \\
\text { struktur ligand untuk } \\
\text { mengoptimasi } \\
\text { peptida sehingga } \\
\text { memiliki efek } \\
\text { inhibisi terhadap } \\
\text { bakteri E.coli } \\
\text { resisten obat }\end{array}$ & $\begin{array}{l}\text { Peptida seperti } \\
\text { PrAMPs (Api88 } \\
\text { dan Onc72) } \\
\text { memiliki potensi } \\
\text { untuk melawan } \\
\text { E.coli resisten } \\
\text { obat }\end{array}$ \\
\hline $\begin{array}{l}\text { Otvos et } \\
\text { al. }\end{array}$ & 2018 & $\begin{array}{l}\text { Penelitian } \\
\text { Eksperimental }\end{array}$ & $\begin{array}{l}\text { Synergy Between } \\
\text { Proline-Rich } \\
\text { Antimicrobial } \\
\text { Peptides and } \\
\text { Small Molecule } \\
\text { Antibiotics } \\
\text { Against Selected } \\
\text { Gram-Negative } \\
\text { Pathogens in } \\
\text { vitro and in vivo }\end{array}$ & $\begin{array}{l}\text { Menggunakan } \\
\text { peptida yang } \\
\text { sekuens asam amino } \\
\text { nya memiliki } \\
\text { kesamaan dengan } \\
\text { A3-APO kecuali } \\
\text { pada satu residu } \\
\text { untuk melihat efek } \\
\text { antimikroba } \\
\text { terhadap bakteri } \\
\text { gram negatif }\end{array}$ & $\begin{array}{l}\text { Kombinasi } \\
\text { antibiotik seperti } \\
\text { imipenem dan } \\
\text { kolistin dengan } \\
\text { A3-APO } \\
\text { memiliki potensi } \\
\text { untuk melawan } \\
\text { bakteri gram } \\
\text { negatif resisten } \\
\text { obat }\end{array}$ \\
\hline
\end{tabular}

\section{Diskusi}

Metode untuk mengontrol bakteri E.coli yang resisten secara garis besar dibagi menjadi dua, yaitu (1) metode killing, yaitu metode yang digunakan untuk melisiskan bakteri secara langsung dan (2) metode inhibisi transkonjugasi, yaitu metode yang digunakan untuk menghambat terjadinya transfer plasmid yang mengkode gen resisten. Metode killing mencakup metode dengan menggunakan CRISPR-Cas9, CRISPR-CasTipe1E, metode lisis bakteri dengan menggunakan CRISPR-Cas9.6,7 


\section{Review Article}

Berdasarkan penelitian, metode transformasi plasmid CRISPR-Cas9 dapat menggantikan peran antibiotik. Plasmid CRISPR-Cas9 yang didapat dari Streptococcus pyogenes dapat dijadikan agen untuk membasmi bakteri resisten antibiotik. ${ }^{7,8}$ Plasmid tersebut akan dimodifikasi sehingga terbentuk suatu single guide RNA (sgRNA) yang berisi RNA Cas9, CRISPR RNA, dan tracrRNA. CRISPR RNA selanjutnya akan berisikan spacer RNA dan 2 segmen RNA dengan urutan basa nukleotida yang sama, namun berbeda dari spacer RNA, mengapit spacer RNA tersebut. Spacer RNA ini selanjutnya akan berkomplemen dan mengikat DNA template atau nontemplate sehingga ikatan untai ganda DNA pada segmen yang diikat akan terlepas. Agar dapat berfungsi sebagai nuklease, Cas9 harus mengenal segmen PAM (Protospacer Adjacent Motive) berupa -NGG jika Cas9 bersumber dari Streptococcus pyogenes. Jika PAM telah ditemukan, Cas9 akan memotong pada daerah spacer melekat, yang disebut daerah protospacer, kemudian akan terjadi mutasi pada DNA dan defek fungsi DNA. ${ }^{15}$

Uji yang dilakukan terhadap E. coli dengan melakukan transformasi plasmid CRISPRCas9 yang berisi spacer RNA sebagai genome target terhadap gen neomycin phosphotransferase pada E. coli, menyebabkan sel sulit bertumbuh sehingga pada media agar LB dengan $170 \mathrm{ug} / \mathrm{mL}$ chloramphenicol, yang hidup hanya 8 sel saja. Sebagai perbandingan, jika plasmid CRISPR-Cas 9 mengandung genome nontarget maka tidak akan terjadi reaksi pengikatan dan pemotongan pada gen sehingga $E$. coli tetap tumbuh dengan jumlah 1920 sel. $^{6}$

Penelitian yang dilakukan oleh Gomaa et al. Membuktikan bahwa sistem CRISPR-Cas memiliki nuklease dengan bentuk biomolekuler berbeda dari Cas9 yakni Cas1E yang terbukti dapat membunuh bakteri E. coli. Penelitian dilakukan dengan mendesain pCRISPR dengan spacer yang mengikat protospacer gen ftsA, suatu gen yang berperan dalam pembelahan sel. Gomaa AA et al. membuktikan bahwa spesifisitas yang dimiliki spacer terhadap protospacer memberikan pengaruh terhadap efesiensi transformasi sel yang berhasil dibunuh. Efisiensi transformasi terbaik $\left(<10^{-5}\right)$ didapatkan dari ikatan sempurna antara spacer dan protospacer tanpa mutasi dari kedua belah pihak. Mutasi pada satu nukleotida (posisi 2 dan 5 dari PAM) menyebabkan peningkatan efisiensi transformasi menjadi $10^{-5}-10^{-4}$. Efisiensi transformasi meningkat menjadi $10^{-4}-10^{-2}$ jika terdapat mutasi pada dua nukleotida dan $10^{0}$ jika mutase pada tiga nukleotida. Khusus untuk mutasi pada posisi nukleotida ke-7 dari PAM, jenis mutasi satu atau dua nukleotida, menghasilkan efisiensi transformasi yang relatif sama jika dibandingkan dengan tanpa terjadinya mutasi. Dari penjelasan di atas, dapat disimpulkan bahwa efisiensi transformasi dipengaruhi oleh tempat terjadinya mutasi. ${ }^{7}$ 


\section{Review Article}

Pada penelitian Gomaa dikatakan bahwa hasil efisiensi transformasi terendah diakibatkan oleh delesi yang terjadi pada pCRISPR selama transformasi dilakukan. Terdapat 10 jenis spacer untuk ditargetkan pada protospacernya masing-masing. Sisa sel yang hidup jumlahnya relatif sama jika dibandingkan apabila target spacer adalah gen $f t s A$. Pengurangan jumlah sel hidup lebih berkaitan erat dengan adanya kerusakan kromosom dan bukan berdasarkan target pada gen yang memiliki fungsi tertentu. Pada penelitian sebelumnya dikatakan bahwa terdapat beberapa spacer yang menargetkan berbagai gen ( $a s d, m s b A$, ftsA, dan nusB) dalam satu pCRISPR. Hasil efisiensi transformasi yang didapatkan relatif sama jika dibandingkan dengan hanya menggunakan satu spacer yang menargetkan gen ftsA saja. Pengurangan jumlah ulangan segmen yang mengapit spacer dapat menangkal terjadinya mutasi pada pCRISPR. Hasil penelitian ini menunjukkan bahwa apabila dua sel memiliki homologi yang tinggi pada genomnya misalnya pada E. coli K12 dan E. coli BL21 (memiliki homologi sekuens genom sekitar 99\%), penargetan spacer dan Cas pada protospacer dan sekuens PAM yang sama pada kedua sel akan menghasilkan dampak kerja yang sama yakni keduanya akan mengalami pemotongan pada protospacer yang bersangkutan. ${ }^{7}$

Penggunaan metode CRISPR-Cas selanjutnya dimodifikasi oleh Cui et al. Melalui penelitiannya dilakukan penambahan komponen berupa protein gam yang berasal dari bakteriofage $\mathrm{Mu}$. Protein gam adalah protein yang berasal dari gen gam dan ditemukan pada bakteriofage Mu bakteri. Protein gam dapat berikatan dengan ujung segmen DNA yang baru mengalami pemotongan oleh Cas9. Protein gam kemudian akan menghambat terjadinya perbaikan DNA baik metode Homologous Recombination (HR) maupun Non-Homologous End Joining (NHEJ). Delesi yang terjadi pada protospacer akan mengakibatkan inaktivasi fungsi gen. Spacer yang ada didesain untuk menargetkan 12 gen yang berbeda pada lokasi gen non-esensial. Percobaan dilakukan pada sel yang memiliki atau tidak memiliki gen $\operatorname{Rec} A$, sebuah gen yang berperan dalam inisiasi respon SOS untuk perbaikan sel. Transformasi pCRISPR dengan spacer target kepada 12 gen terhadap E.coli yang memiliki RecA akan menghasilkan CFU $10^{\circ}$. Hal ini mengindikasikan bahwa apabila E.coli tidak mempunyai gen RecA maka sel kehilangan kemampuan perbaikan sehingga sel akan lebih mudah dibunuh. Akan tetapi jika target sel adalah E. coli tanpa gen $\operatorname{RecA}$ maka sel-sel lain yang masih memiliki RecA masih dapat melakukan perbaikan dan CFU yang didapat rata-rata adalah $10^{1}-10^{4}$. Penelitian ini memperjelas hasil penelitian Gomaa AA et al. yang mengatakan bahwa jika spacer menargetkan suatu gen yang memang krusial dalam tumbuh kembang sel tersebut dan pemotongan oleh Cas9 berhasil menyebabkan terjadinya mutasi dan inaktivasi fungsi gen krusial tersebut, maka jumlah sel yang mati akan menunjukkan peningkatan yang signifikan. Khusus untuk spacer yang ditujukan pada 


\section{Review Article}

gen $t s u B$, wcaH, lacZ1, lacZ2, rpsL, mhpR, speA, yfaP menunjukkan CFU yang lebih rendah dari kontrol. Antara lacZ1 dan lacZ2 meskipun merupakan sesama gen lacZ namun hasil CFU menunjukkan lacZ2 lebih rendah $\left(\sim 10^{1}\right)$ daripada lacZ2 $\left(\sim 10^{3}\right)$. Perbedaan CFU yang jauh ini disebabkan karena lacZ2 tidak memiliki segmen DNA yang homolog dengannya untuk terjadinya proses HR sehingga karena defisiensi repair template inilah yang menyebabkan lacZ2 lebih mudah menyebabkan sel mati. Kemudian apabila transformasi pCas9 dengan target spacer adalah gen lacZ1 atau lacZ2, dilakukan pada E.coli yang memiliki pLC13 pengkode protein gam maka akan didapatkan hasil CFU untuk lacZ1 lebih sedikit 242x lipat, LacZ2 didapatkan CFU lebih sedikit 15x lipat jika dibandingkan dengan tanpa adanya ekspresi protein gam. Disimpulkan bahwa keberadaan protein gam meningkatkan efektivitas kerja sistem CRISPR-Cas9. ${ }^{8}$

Modifikasi metode CRISPR-Cas9 menggunakan media bakteriofag yang dapat memudahkan transfer plasmid tersebut ke bakteri lain. Perlu diketahui bagaimana cara untuk memasukkan plasmid ke dalam kapsid fage. ${ }^{9}$ Pengemasan fagemid ke dalam kapsid phage $M 13$ dibutuhkan suatu sinyal agar pengemasan berhasil untuk selanjutnya ditransfer ke sel bakteri lain. Sinyal transfer ini bernama M13ori yang disisipkan ke dalam plasmid ( $p S B 1 C 3$ ) yang memiliki gen resistensi kloramfenikol. Hasil menunjukkan bahwa saat dibandingkan dengan plasmid yang disisipkan gen Amil-CP, E. coli dengan pSB1C3-M13ori dapat tumbuh pada media agar LB dengan $170 \mathrm{ug} / \mathrm{mL}$ kloramfenikol. pSB1C3-Amil-CP tidak mengandung gen pengemas yang menyebabkan plasmid yang berisikan gen resistensi antibiotik kloramfenikol tidak berhasil dikemas sehingga menyebabkan E. coli tidak dapat tumbuh pada media tersebut. ${ }^{9,10}$ Dengan mengetahui cara efektif dalam mengemas plasmid yang diinginkan maka metode CRISPR-Cas9 dengan mediasi bakteriofage dapat menjadi pilihan yang tepat untuk membunuh bakteri resisten antibiotik. Penyisipan M13-ori ke phagemid CRISPR-Cas9 dilakukan dengan tujuan pengemasan phagemid CRISPR-Cas9 yang dimasukkan ke dalam kapsid fage. ${ }^{11}$

Pembuatan plasmid pembantu M13g6Al akan berguna untuk memroduksi protein pembuat struktur fage M13. Hasil penelitian menunjukkan bahwa E. coli yang mendapatkan phagemid berisi spacer RNA target hanya tersisa 11 koloni sementara jika mendapatkan phagemid berisi gen non-target bakteri E. coli dapat tetap tumbuh dengan jumlah koloni 143 sel. Metode ini terbukti dapat membunuh bakteri resisten antibiotik. ${ }^{6}$ Transfer phagemid dengan mediasi fage M13 sebagai alat transportasi menjadi lebih mudah, sehingga dapat menjangkau semua sel bakteri target maupun non-target. Hasil koloni yang hidup pada bakteri non-target lebih sedikit pada metode ini, mungkin disebabkan oleh adanya spacer yang salah mengikat (off-target) pada segmen gen F' episome yang bertindak sebagai faktor fertilitas. ${ }^{6}$ 


\section{Review Article}

Salah satu metode terbaru yang diteliti oleh Kumari M. et al. Adalah potensi partikelnano perak sebagai alternatif pengganti antibiotik. Metode ini tidak sepenuhnya menggantikan antibiotik karena penelitian dilakukan dengan teknik menggabungkan partikel-nano perak dengan antibiotik sehingga didapatkan hasil efektivitas yang lebih tinggi. Partikel-nano perak ini diperoleh dari larutan $\mathrm{AgNO}_{3}$ yang dimasukkan ke dalam ekstrak Trichoderma viride disentrifugasi dalam inkubator lalu dipajankan dalam lingkungan yang suhu, $\mathrm{pH}$, dengan rentang waktu yang bervariasi. Dengan variasi lingkungan yang berbeda-beda didapatkan ukuran dan bentuk partikel-nano perak yang bervariasi pula. Bentuk dan ukuran partikel-nano perak yang didapatkan adalah bulat dengan ukuran 2-5 (dibuat melalui pajanan lingkungan $30^{\circ} \mathrm{C}, \mathrm{pH} 7$, lama inkubasi 24 jam), 3-20, 40-50 nm; persegi panjang 40-65 nm (dibuat melalui pajanan lingkungan $40^{\circ} \mathrm{C}, \mathrm{pH} \mathrm{5}$, lama inkubasi $72 \mathrm{jam}$ ); penta/hexagonal 50-100 $\mathrm{nm}$ (dibuat melalui pajanan lingkungan $40^{\circ} \mathrm{C}, \mathrm{pH}$ 9, lama inkubasi 72 jam). ${ }^{11}$ Perbedaan bentuk dan ukuran partikel yang didapatkan dipengaruhi oleh adanya perbedaan aktivasi enzim yang terjadi akibat pengaruh lingkungan yang diberikan. Dari semua bentuk dan ukuran partikel di percobaan ini hasil yang paling baik adalah partikel terkecil $2-5 \mathrm{~nm}$ dengan bentuk bulat yang ditandai dengan zona inhibisi terhadap E. coli sebesar $23,6 \mathrm{~mm}$. Hasil untuk CFUnya berkurang hingga $51 \%$. Efektivitas partikel ini dibandingkan dengan bentuk penta/hexagonal 50-100 nm adalah 8-10\% lebih baik. Untuk partikel bulat dengan ukuran 40-50 nm, efektivitasnya lebih buruk 15-18\% daripada partikel penta/hexagonal berukuran sama. Jika penggunaan partikel-nano perak ini digabungkan dengan pemakaian antibiotik Ampisilin dan Penisilin, zona inhibisi akan mengalami peningkatan 40-45\% untuk partikel persegi panjang $(40-65 \mathrm{~nm})$ dan penta/hexagonal (50-100 $\mathrm{nm})$. Untuk partikel bulat $(2-5 \mathrm{~nm})$ zona inhibisinya meningkat hingga 50\%. Peningkatan zona inhibisi juga terjadi pada penggunaan yang sinergistik dengan Kanamisin (80\%), Streptomisin (90-100\%), Tetrasiklin (150-180\%) dengan hasil maksimal didapat jika menggunakan partikel bulat ukuran $2-5 \mathrm{~nm} .^{9}$

Pada studi oleh Rai et al. Dinyatakan bahwa peran yang dilakukan oleh partikel-nano perak berpotensi sebagai bakterisidal maupun bakteriostatik untuk melawan bakteri resisten. ${ }^{10}$ Pada penelitian tersebut dijelaskan bahwa partikel-nano perak dapat melakukan penempelan pada membran sel, penetrasi dan mengganggu permeabilitas sehingga mengganggu sistem transport dan berakhir pada kematian sel. Partikel ini juga berpotensi untuk menjadi senyawa radikal bebas yaitu dengan berikatan dengan gugus tiol (-SH) dan mengkatalisis pembentukan ikatan disulfida pada enzim vital sel seperti subunit ribosom 30s sehingga menginaktivasi kompleks ribosom dan menghambat translasi protein. Enzim lain seperti Suksinil KoA sintase yang berperan dalam 


\section{Review Article}

siklus asam sitrat juga berkurang karena adanya partikel ini. Ion $\mathrm{Ag}^{+}$juga dapat berinterkalasi di antara basa purin dan pirimidin DNA sehingga mengganggu ikatan hidrogen dan menyebabkan denaturasi DNA. Partikel ini juga mempengaruhi sistem phosphotyrosine profiling sehingga mempengaruhi mekanisme sinyal sel yang berdampak pada inhibisi pertumbuhan bakteri. Partikel ini juga dapat menghambat pembentukan komponen biofilm bakteri yang merupakan suatu matriks polisakarida ekstraselular yang disekresi oleh bakteri sebagai lapisan pelindung bakteri dari serangan antimikrobial. Inhibisi sintesis biofilm oleh partikel-nano perak menyebabkan bakteri akan kembali rentan terhadap antibiotik. ${ }^{10}$

Metode selanjutnya yang digunakan untuk mengontrol populasi bakteri resisten E.coli adalah dengan menghambat proses transkonjugasi bakteri (proses pemindahan plasmid dari 1 bakteri ke bakteri lainnya) yang berperan besar dalam penyebaran gen resisten. Proses yang harus dilakukan pertama kali yaitu apabila bakteri memiliki plasmid F (Fertility), maka bakteri tersebut dikatakan $F+$ cell dan akan berekspresi dari plasmid $\mathrm{F}$ itu adalah sel memiliki F pilus/ F pili yang pilus tersebut digunakan sebagai jembatan pemindahan plasmid berisikan gen resisten (conjugative pilus). Penelitian yang dilakukan Zhang et al. Menunjukkan bahwa disamping kelebihannya dalam memediasi pemindahan plasmid, pili tersebut juga menjadi tempat menempelnya filamentous bacteriophage (famili bakteriofage yang merupakan untaian tunggal dan melekat pada ujung pilus). Filamentous bacteriophage ini (M13, Fd dan F1) melekat pada F pilus dan menyebabkan fage mampu memasukkan genomenya ke dalam bakteri tersebut. ${ }^{13}$ Mekanisme infeksi yang terjadi antara bakteri $\mathrm{F}+$ dan Fage filamentous ini dimediasi oleh protein g3p yang terletak di minor coat dari fage M13. Protein g3p merupakan 406 asam amino yang terbagi dalam 3 domain dan dibatasi melalui suatu ikatan glisin. Satu protein yang memiliki domain N-terminal (N2) akan mengikat ujung dari F pilus. Protein lain pada domain N-terminal (N1) akan mengikat pada domain C -terminal dari protein TolA (merupakan suatu koreseptor untuk filamentous bacteriophage). ${ }^{4,11}$

Dampak yang ditimbulkan dengan adanya perlekatan antara fage M13 ini dengan F pilus adalah: ${ }^{14}$ (1) Fage membentuk infeksi kronik yang menyebabkan penurunan kesehatan sel sebesar 30-50\% yang berakibat pada menurunnya jangka waktu hidup sel tersebut, (2) Fage membentuk infeksi yang menyebabkan jumlah F pilus pada bakteri menurun sampai hanya tersisa 0-3 pilus yang menyebabkan menurunnya kapasitas $F+$ cell dalam perannya sebagai donor dalam kejadian transkonjugasi, (3) Protein g3p yang menempel di ujung F pilus akan menghambat perlekatan dari $F+$ cell dengan $F$ - cell dan mencegah terjadinya transkonjugasi bakteri, dan yang terakhir (4) 


\section{Review Article}

Ekspresi berlebihan pada domain N-terminal g3p menyebabkan periplasmic localization yang nantinya akan menghambat terjadinya transkonjugasi antar bakteri. ${ }^{12}$

Terdapat penelitian mengenai efek mutasi pada bakteri yang menjadi resipien dari transkonjugasi selain inhibisi konjugasi bakteri yang dilakukan kepada bakteri donor. ${ }^{12}$ Penelitian dilakukan dengan menginsersi plasmid Psu 2007::Tnlux yang merupakan derivat dari plasmid R388 yang memberikan efek pancaran cahaya pada bakteri. Plasmid diberikan kepada bakteri $E$. coli UCDPM1 yang akan berperan sebagai donor dan kemudian digabungkan dengan 3908 bakteri E. coli Keio yang mengalami delesi gen tunggal dan 20.000 bakteri E. coli tipe liar yang mengalami mutasi gen secara acak dengan diberikan mini-Tn10::Km. Hasil yang didapat menunjukkan bahwa setelah proses transkonjugasi sudah selesai, cahaya yang dipancarkan oleh E. coli Keio maupun $E$. coli mini-Tn10 menunjukkan pancaran yang sama dengan bakteri kontrol tetapi hanya 38 bakteri Keio dan 237 bakteri mini-Tn10 yang memberikan Arbitary Light Units $<1$. Hal ini menunjukkan mutasi yang terjadi pada bakteri yang menjadi resipien tidak terlalu mempengaruhi kejadian transkonjugasi. ${ }^{13,16}$

Metode yang berpotensi untuk dilakukan selain menggunakan bakteriofag dan inhibisi transkonjugasi, adalah Antimicrobial Peptide (AMP). Berdasarkan penelitian yang dilakukan oleh Szabó et al., desain dimer A3-APO Proline-rich Antimicrobial Peptide (PrAMP) mampu menjadi harapan dalam mengatasi permasalahan resistensi antibiotik. Peptida proline-rich adalah peptida kationik dengan kandungan residu prolin tinggi yang diisolasi terutama dari spesies serangga. Dalam beberapa tahun terakhir, peptida ini banyak diteliti dan melalui berbagai evaluasi dari penelitian peptida proline-rich, didapatkan hasil berupa APO (All Peptide Optimized). Chex adalah Cyclohexane-carboxylic acid dan Dab adalah 1,3-diamino-propionic acid. ${ }^{14}$ A3-APO memiliki mekanisme kerja dengan berikatan secara selektif pada regio C-terminal helix di 70 $\mathrm{kDa}$, yaitu DnaK (bacterial heat shock protein). Aktivitas DnaK diinhibisi sehingga proses protein refolding sel terganggu. ${ }^{15}$ Peptida ini dapat membunuh sel bakteri terutama kelompok Enterobacteriaceae, termasuk E.coli. ${ }^{16}$

Pada percobaan secara in vitro pada 13 E.coli dengan MDR, hasil MIC berkisar pada 2 $\mathrm{mg} / \mathrm{L}$ sampai $>64 \mathrm{mg} / \mathrm{L} .{ }^{16}$ Percobaan secara in vivo juga dilakukan pada tikus dengan hasil peptida ini mampu membunuh bakteri gram negatif yang resisten terhadap betalaktam dan fluoroquinolone dengan MIC rata-rata $12 \mathrm{mg} / \mathrm{L}$. A3-APO mampu bekerja secara sinergis dengan antibiotik yang memiliki molekul kecil. Saat diujikan secara in vitro pada E.coli, peptida menunjukkan kerja yang sinergis: E.coli S5081, dengan trimetoprim (FIC: 0.38) dan kloramfenikol (FIC: 0.31); E.coli BF1023 dengan amoksisilin (FIC: 0.75); E. coli SEQ102, 


\section{Review Article}

dengan trimetoprim, kloramfenikol, dan amoksisilin (FIC: 0.56); E. coli 5770, dengan kloramfenikol (FIC: 0.31). ${ }^{14,17}$ Metode menggunakan dimer A3-APO yang merupakan metode terbaik untuk mengontrol populasi E.coli yang resisten obat karena A3-APO merupakan suatu peptida antimikroba dengan efektivitas $99 \%-100 \% .^{16,17}$

Untuk metode inhibisi menggunakan teknik transkonjugasi. Inhibisi terhadap bakteri resipien ternyata menunjukkan hasil yang tidak memuaskan karena hanya menunjukkan efektivitas sebesar 0,97\%-1,19\%.

\section{Simpulan}

Metode terbaik untuk mengontrol populasi E.coli yang resisten obat adalah mengganggu dan merusak aktivitas protein folding bakteri dengan dimer A3-APO yang merupakan suatu peptida antimikroba dengan hasil efektivitas sebesar 99\%-100\%.

\section{Daftar Pustaka}

1. Boeckel TPV, Gandra S, Ashok A, Caudron Q, Grenfell BT, Levin SA, et al. Global Antibiotic Consumption 2000 to 2010: an Analysis of National Pharmaceutical Sales Data. Lancet Infect Dis. 2014;14(8):742-50.

2. Boeckel TPV, Brower C, Gilbert M, Grenfell BT, Levin SA, Robinson TP, et al. Global Trends in Antimicrobial Use in Food Animals. Proc Natl Acad Sci. 2015;112(18):5649-54.

3. Nga DTT, Chuc NTK, Hoa NP, Hoa NQ, Nguyen NTT, Loan HT, et al. Antibiotic Sales in Rural and Urban Pharmacies in Northern Vietnam: an Observational Study. BMC Pharmacol Toxicol. 2014;15(1):6.

4. Kang C-I, Song J-H. Antimicrobial Resistance in Asia: Current Epidemiology and Clinical Implications. Infect Chemother. 2013;45(1):22-31.

5. Pitout JDD. Extraintestinal Pathogenic Escherichia coli: A Combination of Virulence with Antibiotic Resistance. Front Microbiol [Internet]. 2012 Jan 19 [cited 2021 May 20];3. Available from: https://www.ncbi.nlm.nih.gov/pmc/articles/PMC3261549/

6. Cai JC, Zhang R, Hu YY, Zhou HW, Chen G-X. Emergence of Escherichia coli Sequence Type 131 Isolates Producing KPC-2 Carbapenemase in China. Antimicrob Agents Chemother. 2014 Feb 1;58(2):1146-52.

7. Gomaa AA, Klumpe HE, Luo ML, Selle K, Barrangou R, Beisel CL. Programmable Removal of Bacterial Strains by Use of Genome-Targeting CRISPR-Cas Systems. mBio. 2014 ; 5(1):e00928-33.

8. Cui L, Bikard D. Consequences of Cas9 Cleavage in The Chromosome of Escherichia coli. Nucleic Acids Res. 2016 ;44(9):4243-51.

9. Kumari M, Pandey S, Giri VP, Bhattacharya A, Shukla R, Mishra A, et al. Tailoring Shape and Size of Biogenic Silver Nanoparticles to Enhance Antimicrobial Efficacy Against MDR Bacteria. Microb Pathog. 2017 Apr $1 ; 105(3): 346-55$

10. Rai MK, Deshmukh SD, Ingle AP, Gade AK. Silver Nanoparticles: the Powerful Nanoweapon Against MultidrugResistant Bacteria. J Appl Microbiol. 2012;112(5):841-52.

11. Liu B, Huang H, Yang Z, Liu B, Gou S, Zhong C, et al. Design of Novel antimicrobial Peptide Dimer Analogues with Enhanced Antimicrobial Activity in Vitro and in Vivo by Intermolecular Triazole Bridge Strategy. Peptides. 2017;88(2):115-25.

12. Lin A, Jimenez J, Derr J, Vera P, Manapat ML, Esvelt KM, et al. Inhibition of Bacterial Conjugation by Phage M13 and Its Protein g3p: Quantitative Analysis and Model. PLOS ONE. 2011; 26;6(5):e19991. https://doi.org/10.1371/journal.pone.0019991

13. Zhang Y, Liu Y, Sun Y, Liu Q, Wang X, Li Z, et al. In Vitro Synergistic Activities of Antimicrobial Peptide Brevinin-2CE with Five Kinds of Antibiotics Against Multidrug-Resistant Clinical Isolates. Curr Microbiol. 2014;68(6):685-92. 


\section{Review Article}

14. Krizsan A, Knappe D, Hoffmann R. Influence of the yjiL-mdtM Gene Cluster on the Antibacterial Activity of Proline-Rich Antimicrobial Peptides Overcoming Escherichia coli Resistance Induced by the Missing SbmA Transporter System. Antimicrob Agents Chemother. 2015;59(10):5992-8.

15. Knappe D, Goldbach T, P.D. Hatfield M, Y. Palermo N, Weinert S, Sträter N, et al. Proline-rich Antimicrobial Peptides Optimized for Binding to Escherichia coli Chaperone DnaK. Protein Pept Lett. 2016;23(12):1061-71.

16. Szabo D, Ostorhazi E, Binas A, Rozgonyi F, Kocsis B, Cassone M, et al. The Designer Proline-Rich Antibacterial Peptide A3-APO is Effective Against Systemic Escherichia coli Infections in Different Mouse Models. Int J Antimicrob Agents. 2010;35(4):357-61.

17. Otvos Jr. L, Ostorhazi E, Szabo D, Zumbrun SD, Miller LL, Halasohoris SA, et al. Synergy Between Proline-Rich Antimicrobial Peptides and Small Molecule Antibiotics Against Selected Gram-Negative Pathogens in vitro and in vivo. Front Chem. 2018;6(4):309

18. Directorate General of Medical Care Ministry of Health Republic Indonesia. Antimicrobial Resistance, Antibiotic Usage and Infection Control: A Self-Assessment Program for Indonesian hospitals. http://apps.who.int/medicinedocs/ documents/s18010en/s18010en.pdf. Accessed Feb, 2015.

19. Severin JA, Mertaniasih NM, Kuntaman K, Lestari ES, Purwanta M, Lemmens-Den Toom N, et al. Molecular Characterization of Extended-Spectrum $\beta$-lactamases in Clinical Escherichia coli and Klebsiella pneumoniae Isolates from Surabaya, Indonesia. J Antimicrob Chemother. 2010 Mar 1;65(3):465-9.

20. Peraturan Menteri Kesehatan Republik Indonesia Nomor 2406/Menkes/Per/XII/2011. http://www.Binfar.Depkes.Go.Id/Dat/ Permenkes_Antibiotik.Pdf , accessed Feb, 2015

21. Niasono AB, Latif H, Purnawarman T. Resistensi Antibiotik terhadap Bakteri Escherichia coli yang Diisolasi dari Peternakan Ayam Pedaging di Kabupaten Subang, Jawa Barat (Antibiotic Resistance to Escherichia.coli Isolated from Broiler Farms in Subang District, West Java Province). J Vet. 2019;20(2):187-95. 